\title{
EFFECT OF NITRITE ION ON CORROSION INHIBITION OF MILD STEEL IN SIMULATED COOLING WATER
}

\author{
Siragul Karim ${ }^{1}$, C. M. Mustafa ${ }^{1}$, Md. Assaduzzaman ${ }^{1}$, Mayeedul Islam ${ }^{* 2}$ \\ ${ }^{1}$ Dept. of Applied Chemistry and Chemical Technology, University of Rajshahi, Rajshahi-6205, Bangladesh \\ ${ }^{2}$ Dept. of Chemistry, Rajshahi University of Engineering and Technology, Rajshahi-6204, Bangladesh
}

Received 19 April 2010; received in revised form 29 August 2010

\begin{abstract}
Corrosion inhibition of mild steel by sodium nitrite in simulated cooling water (SCW) containing chloride ion was investigated. Electrochemical techniques such as corrosion potential $\left(E_{\mathrm{corr}}\right)$ measurement and potentiodynamic sweep experiments were used. The experimental parameters were concentration of the inhibitor, $\mathrm{pH}$ of the aqueous media and soaking time. Nitrite inhibited mild steel corrosion in near neutral and alkaline ( $\mathrm{pH} 6$ and above) SCW and accelerated corrosion in acidic media ( $\mathrm{pH} 4$ and below). Inhibition activity increased with the increase of nitrite concentration up to 500 ppm, and afterwards remained more or less constant at pH 6 and above. In stagnant SCW, maximum corrosion inhibition was observed at $\mathrm{pH} 8$ for all concentration of $\mathrm{NaNO}_{2}$. Inhibition action of $\mathrm{NaNO}_{2}$ was found to increase with the increase of soaking time up to 24 hours, and afterwards it remained more or less constant at all nitrite concentrations at and above $\mathrm{pH}$ 6. Based on the experimental results, mechanisms of action of $\mathrm{NaNO}_{2}$ on mild steel corrosion inhibition in $\mathrm{SCW}$ have been proposed.
\end{abstract}

Keywords: Corrosion, Potentiodynamic sweep, Inhibitor

DOI:10.3329/cerb.v14i2.4813

\section{Introduction}

Cooling water is an integral part of most of the chemical process and many other industries. This contains aggressive ions which cause corrosion problems in boilers, condensers, heat exchangers, pipe lines, economizers etc. Simulated Cooling Water (SCW) having composition 300 ppm $\mathrm{Cl}^{-}, 351 \mathrm{ppm} \mathrm{SO} \mathrm{SO}_{4}^{2-}, 37 \mathrm{ppm} \mathrm{CO}_{3}^{2-}$, and $123 \mathrm{ppm} \mathrm{HCO}_{3}^{-}$ represents cooling water in industry [1]. Use of inhibitors in controlling corrosion in cooling water systems is the most convenient and economic method compared to others [2]. Among numerous inorganic and organic inhibitors used in the last sixty years nitrite appears to be a promising oxidizing inhibitor for steel $[3,4]$. It produces ferric oxide barrier on the surface of steel against corrosion. Tosun found nitrite as the best inhibitor in effectiveness among chromate, molybdate, benzoate, ascorbic acid and orthophosphate in neutral aqueous media containing $100 \mathrm{ppm} \mathrm{NaCl}$ [5]. Nitrite is also effectively used as inhibition admixture in concrete reinforcement [6-8]. Ramasubramanian reported the inhibition action of calcium nitrite on carbon steel in alkaline chloride containing media [9]. Synergistic inhibition action of nitrite in conjunction with chromate, molybdate, ascorbic acid, benzoate, ortho phosphate has been reported in the literature [9-12]. Most of the investigations on the inhibition effects of nitrite have been carried out in chloride free or in low chloride neutral or alkaline aqueous environment in ideal condition [9-12]. A systematic investigation on the corrosion inhibition of mild steel by nitrite in SCW in realistic condition can be found in the work of Mustafa

*Corresponding author, Email:mayeedul180@yahoo.com et.al.[10, 12]. So, the present investigation is aimed to study the effectiveness of sodium nitrite on the corrosion inhibition of mild steel in realistic aqueous media like SCW in acidic and alkaline environment.

\section{Experimentals}

Commercial grade mild steel coupons (composition: 0.10 $\%$ C, $0.25 \% \mathrm{Mn}, 0.01 \% \mathrm{Si}, 0.01 \% \mathrm{P}, 0.018 \% \mathrm{~S}$ ) having dimension $4 \mathrm{~cm} \times 2 \mathrm{~cm} \times 0.1 \mathrm{~cm}$ were used in all experiments. The compositional analyses of the mild steel have been carried following the procedures described elsewhere[13]. The coupons were polished to mirror finish, degreased with acetone and rinsed in distilled water. The specimens were then insulated with synthetic paint leaving $1 \mathrm{~cm} \times 1 \mathrm{~cm}$ area exposed for experiment. These were then dried in open air and stored in a desiccator over silica gel for subsequent use.

The base electrolyte, simulated cooling water (SCW), was prepared by dissolving 500 ppm $\mathrm{NaCl}, 520$ ppm $\mathrm{Na}_{2} \mathrm{SO}_{4}$, 170 ppm anhydrous $\mathrm{NaHCO}_{3}$, and $66 \mathrm{ppm} \mathrm{Na}_{2} \mathrm{CO}_{3}$ per liter of distilled water. Inhibitor solution was prepared by dissolving appropriate amount of sodium nitrite in the SCW. The $\mathrm{pH}$ of the solution was adjusted by using dilute solutions of $\mathrm{NaOH}$ or $\mathrm{H}_{2} \mathrm{SO}_{4}$. All reagents used in the study were analytical grade chemicals. Electrochemical cell was composed of platinum counter electrode, mild steel coupon as working electrode and saturated $\mathrm{Ag} / \mathrm{AgCl}$ (SSE) as a reference electrode. The corrosion potential $\left(E_{\text {corr }}\right)$ was measured against SSE using high impedance $(1010 \mathrm{ohm})$ electrometer. The potentiodynamic experiment was made by using Hab151 potentiostat at a scan rate of $40 \mathrm{mV} / \mathrm{min}$. 


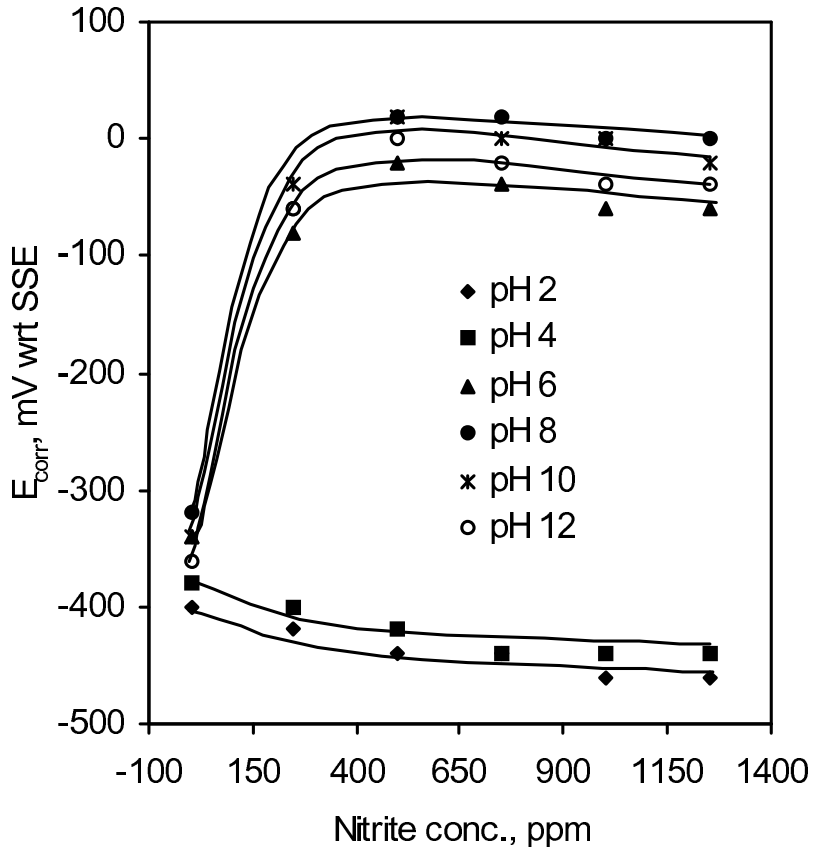

Figure 1: Effect of $\mathrm{NaNO}_{2}$ conc. on the corrosion potential of mild steel. Base electrolyte SCW: soaking time $1 \mathrm{hr}$

\section{Results and Discussion}

Figure 1 shows the effect of $\mathrm{NaNO}_{2}$ concentration on the corrosion potential after $1 \mathrm{hr}$. immersion. Corrosion potential $\left(E_{\text {corr }}\right.$.) steeply increased with the increase of $\mathrm{NaNO}_{2}$ concentration up to $500 \mathrm{ppm}$, and afterwards levelled off for pH 6 and above. At pH 2 and 4 corrosion potential slowly decreased with the increase of $\mathrm{NaNO}_{2}$ concentration. Under identical concentration of $\mathrm{NaNO}_{2} E_{\text {corr }}$ sharply increased with the increase of $\mathrm{pH}$ up to 8 and afterwards slowly decreased at all concentration of $\mathrm{NaNO}_{2}$ as shown in Figure 2.

The effect of soaking time on the corrosion potential of mild steel in stagnant SCW containing $\mathrm{NaNO}_{2}$ is shown in Figure 3. The corrosion potential increased slowly with the increase of soaking time up to 24 hours and then it remained constant up to 48 hours immersion (maximum immersion period) for $\mathrm{pH} 6$ and above. No significant change in corrosion potential was found with the increase of immersion time for pH 2 and 4. As nitrite is known as an anodic corrosion inhibitor, therefore, increase of corrosion potential is an indication of corrosion inhibition. This indicates corrosion inhibition by $\mathrm{NaNO}_{2}$ at $\mathrm{pH} 6$ and above in stagnant SCW, and corrosion aggravation at or below $\mathrm{pH} 4$. Maximum corrosion potental was found at $\mathrm{pH} 8$ containing $500 \mathrm{ppm} \mathrm{NaNO}_{2}$.

The potentiodymanic sweep on the mild steel in SCW containing $\mathrm{NaNO}_{2}$ at $\mathrm{pH} 4$ is shown in Figure 4. Absence of current arrest with the increase of potential is an indication of active corrosion. Early current rise at higher concentration of $\mathrm{NaNO}_{2}$ shows its corrosion acceleration effect in $\mathrm{SCW}$ at $\mathrm{pH} 4$.

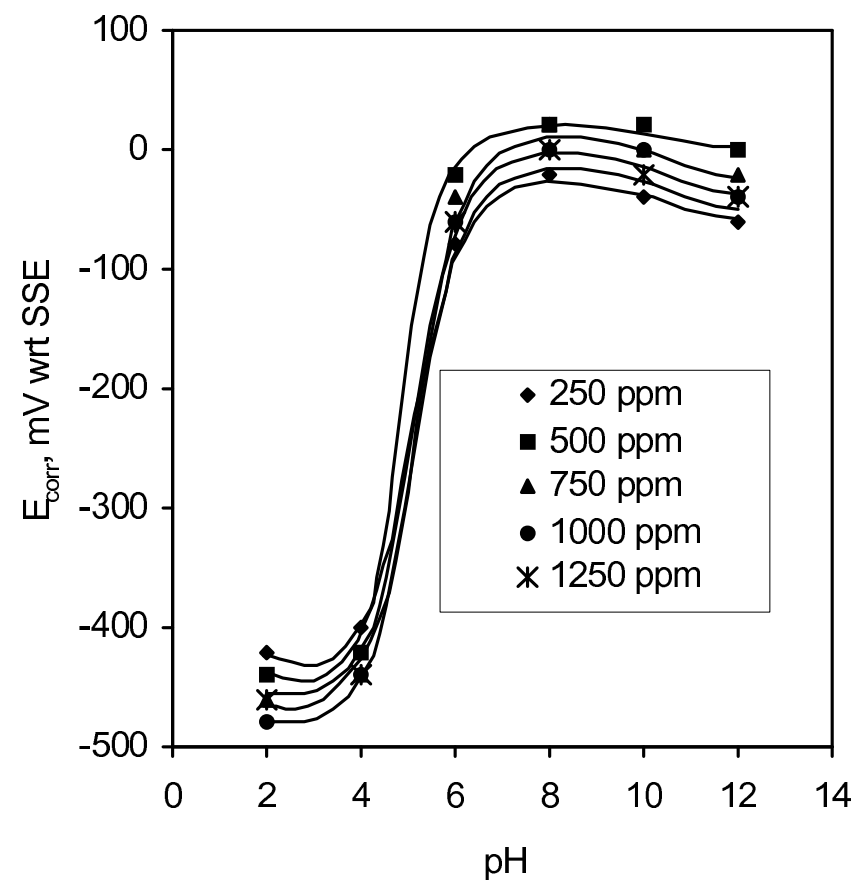

Figure 2: Effect of $\mathrm{pH}$ on the corrosion potential of mild steel. Base electrolyte SCW: soaking time $1 \mathrm{hr}$

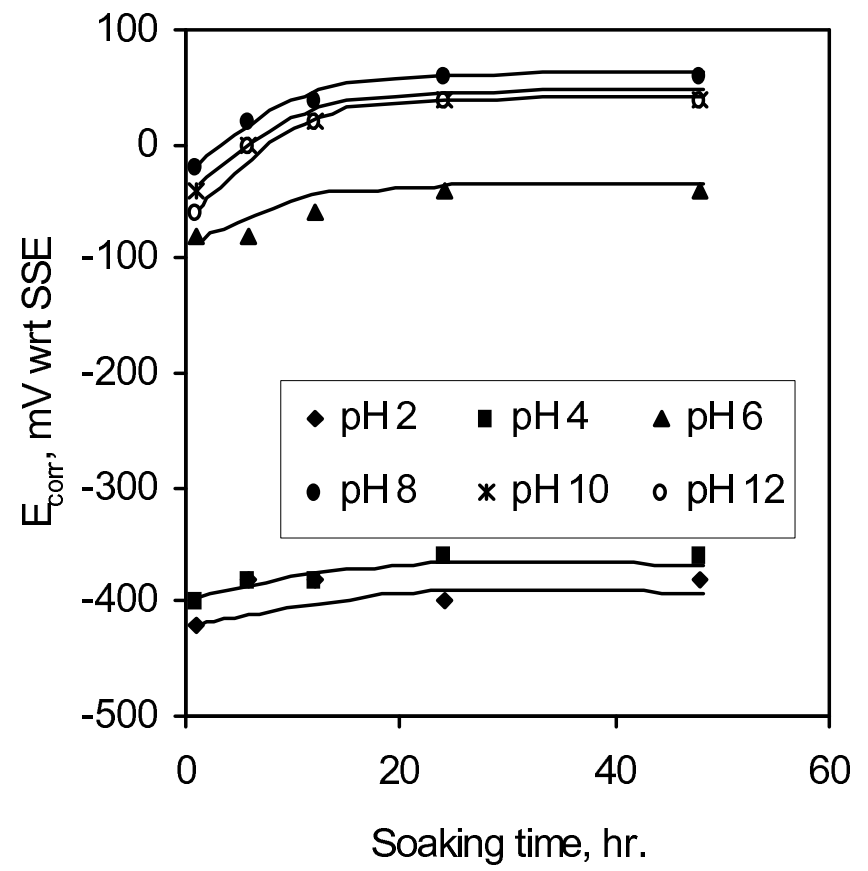

Figure 3: Effect of soaking time on the corrosion potential in SCW containing $250 \mathrm{ppm} \mathrm{NaNO}_{2}$

Figure 5 shows the anodic potentiodynamic sweep on the mild steel in stagnant SCW containing $\mathrm{NaNO}_{2}$ at $\mathrm{pH}$ 6. Current arrest with the increase of potential at all concentration of NaNO2 indicates passivation of mild steel. The extension of passive region was found up to $300 \mathrm{mV}, 460 \mathrm{mV}, 440 \mathrm{mV}$, $440 \mathrm{mV}$ and $440 \mathrm{mV}$ with respect to SSE in the presence of $250 \mathrm{ppm}, 500 \mathrm{ppm}, 750 \mathrm{ppm}, 1000 \mathrm{ppm}$ and $1250 \mathrm{ppm}$ 


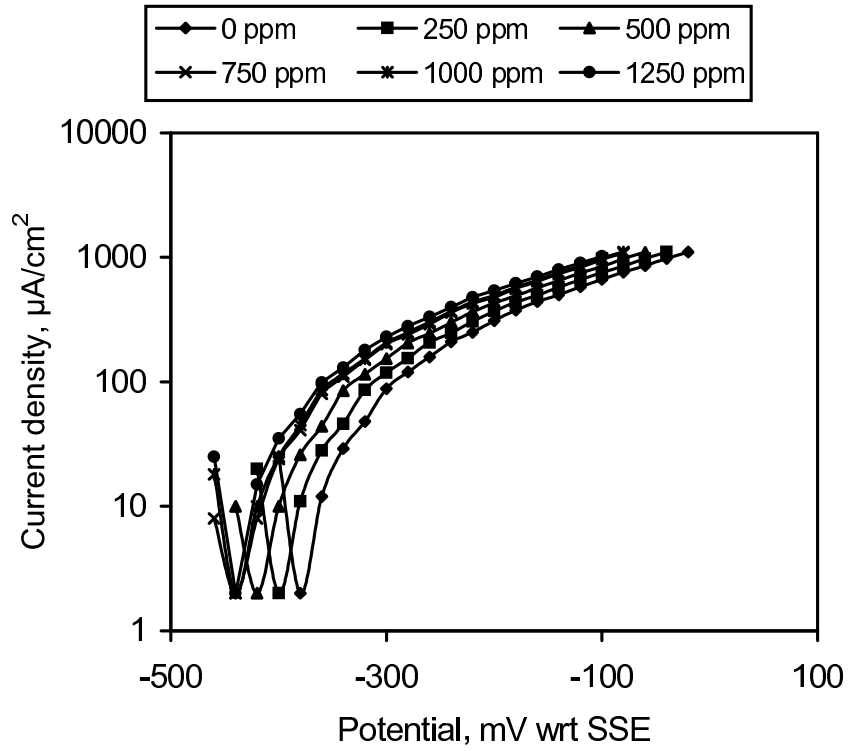

Figure 4: Potentiodynamic sweep on mild steel in SCW containing $\mathrm{NaNO}_{2}$ at $\mathrm{pH}$ 4. Soaking time, $48 \mathrm{hr}$

$\mathrm{NaNO}_{2}$ respectively. The current density having magnitude below $1 \mu \mathrm{A} / \mathrm{cm}^{2}$ in the passive region is an indication of good passivation. As this current density was observed even in the presence of as low as 250 ppm $\mathrm{NaNO}_{2}$ in stagnant SCW it indicates effective corrosion inhibition by $\mathrm{NaNO}_{2}$.

Figure 6 shows the effect of $\mathrm{pH}$ on the anodic potentiodynamic behaviour of mild steel in SCW containing 500 ppm $\mathrm{NaNO}_{2}$. A more extensive passive range was observed at $\mathrm{pH}$ 8 compared to other $\mathrm{pH}$ values. At $\mathrm{pH} 2$ and 4 no passion was observed. These results reveal that $\mathrm{NaNO}_{2}$ is a corrosion inhibitor for mild steel in stagnant $\mathrm{SCW}$ at $\mathrm{pH} 6$ and above and inhibition activity increases with the increase of $\mathrm{NaNO}_{2}$ concentration up to $500 \mathrm{ppm}$.

Results for the effect of $\mathrm{pH}$ on the passivation breakdown potential of the mild steel in $\mathrm{SCW}$ containing $\mathrm{NaNO}_{2}$ are shown in Figure 7 for 24 hour soaking. Passivation breakdown potentials were raised to more noble potentials with the increase of $\mathrm{pH}$ up to 8 and afterwards slowly decreased. The effect of $\mathrm{NaNO}_{2}$ concentration on the passivation breakdown potential of the mild steel is shown in Figure 8. The passivation breakdown potential rapidly increased with the increase of $\mathrm{NaNO}_{2}$ concectration up to $500 \mathrm{ppm}$, and then remained more or less constant.

In stagnant condition diffusion is the only process for ions to reach the surface of the mild steel and this is dependent on the size of the ions and time. In SCW chloride ion present is most harmful for mild steel as it forms highly soluble iron chloride with iron ion. Chloride ion also chemically reacts with the surface barrier oxide to form soluble iron oxy-chloride as $\mathrm{FeOOH}+\mathrm{Cl}^{-} \longrightarrow \mathrm{FeOCl}+\mathrm{OH}^{-}$[14]. The Chloride ion attack on the surface usually takes place at the defects or weak sites of the oxide.

As there is always a competition between aggressive ion and nitrite to breakdown and repair the oxide of the surface; therefore, immersion time of the mild steel in stagnant SCW

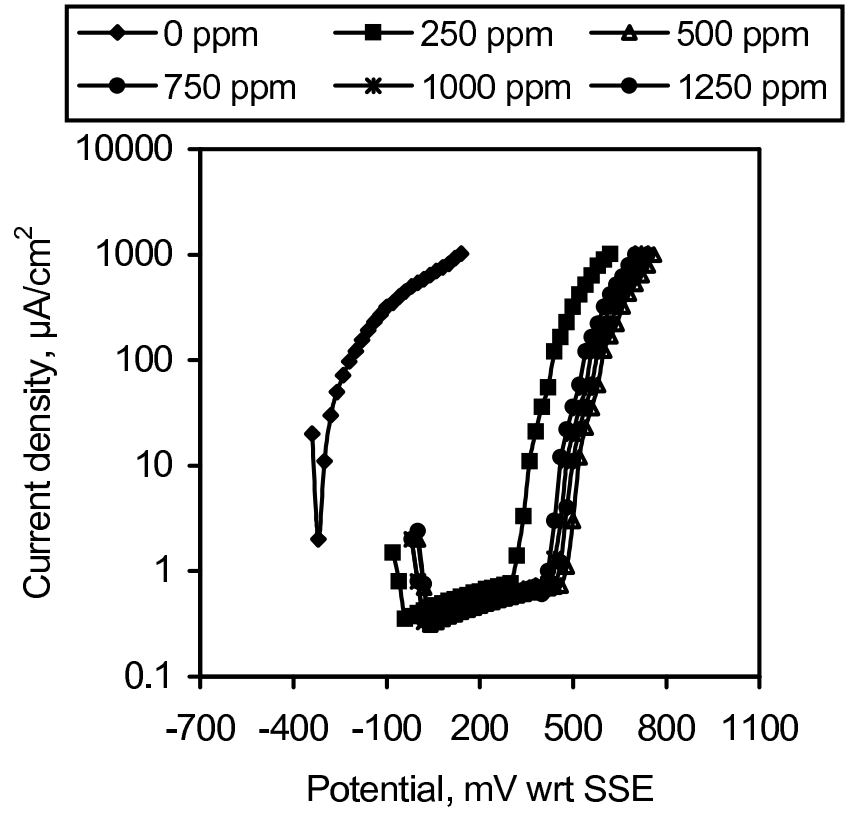

Figure 5: Potentiodynamic sweep on the mild steel in SCW containing $\mathrm{NaNO}_{2}$ at $\mathrm{pH}$ 6. Soaking time, $24 \mathrm{hr}$

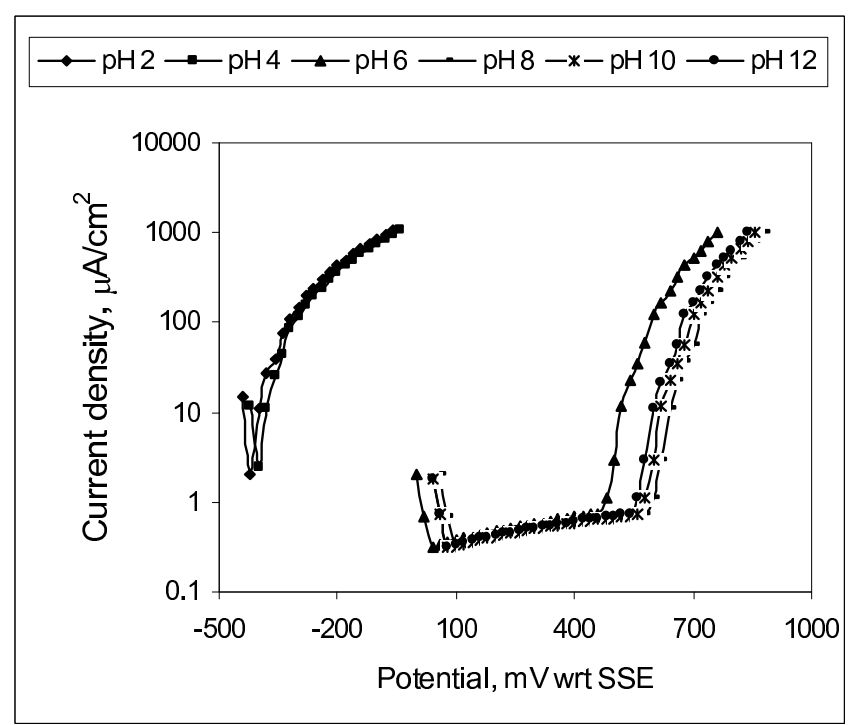

Figure 6: Effect of $\mathrm{pH}$ on the anodic potentiodynamic behaviour of mild steel in SCW containing 500 ppm $\mathrm{NaNO}_{2}$

containing $\mathrm{NaNO}_{2}$ can have an important role on the corrosion inhibition. The effect of soaking time on the passivation breakdown potential in stagnant $\mathrm{SCW}$ containing $\mathrm{NaNO}_{2}$ at pH 6 is shown in Figure 9. The breakdown potential slowly increased with the increase of soaking time up to 24 hours and afterwards it remained more or less constant with the further increase of soaking time up to 48 hours for all $\mathrm{NaNO}_{2}$ concentrations.

Prolonged exposure of mild steel in SCW results in the insertion of chloride ion and water molecule into the structure of $\mathrm{Fe}(\mathrm{OH})_{2}$ leading to $3 \mathrm{Fe}(\mathrm{OH})_{2} \cdot \mathrm{Fe}(\mathrm{OH}) \mathrm{Cl} \cdot \mathrm{nH}_{2} \mathrm{O}$ (green rust, containing chloride) [15]. This also eventually leads to 


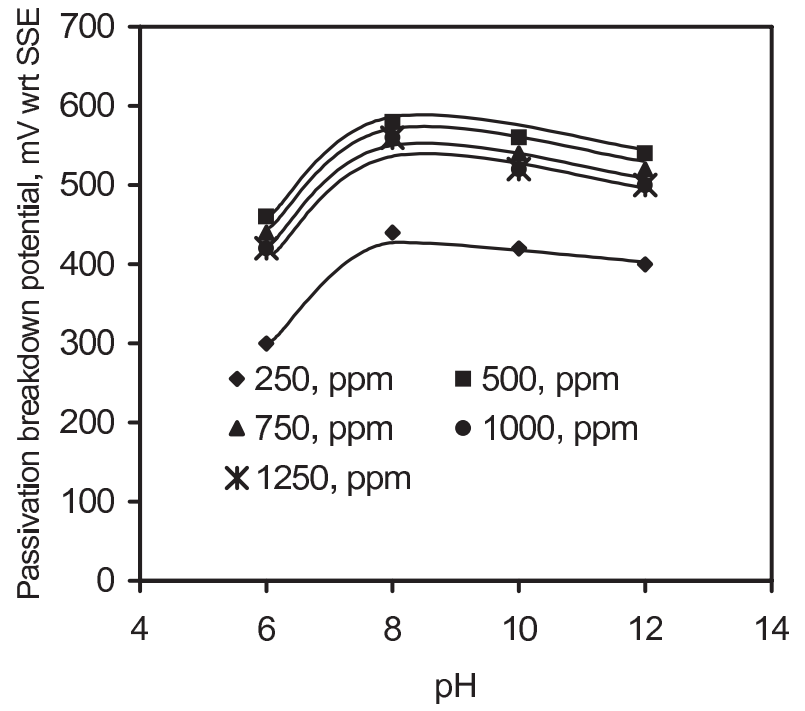

Figure 7: Effect of $\mathrm{pH}$ on passivation breakdown potential in SCW containing $\mathrm{NaNO}_{2}$. Soaking time, $24 \mathrm{hr}$

corrosion.

Ferrous ions produced on the mild steel surface are converted to insoluble and stable ferric oxide in the oxide stability region (near neutral and alkaline region) according to the reaction [9].

$$
2 \mathrm{Fe}^{2+}+2 \mathrm{OH}+2 \mathrm{NO}_{2} \rightarrow 2 \mathrm{NO}+\mathrm{Fe}_{2} \mathrm{O}_{3}+\mathrm{H}_{2} \mathrm{O}
$$

This $\mathrm{Fe}_{2} \mathrm{O}_{3}$ plugs the defects of the oxide layer. Thus the action of nitrite is two fold; firstly because of negative charge it repels $\mathrm{Cl}^{-}$from the surface and secondly it repairs the oxide layer on the surface. These result in very effective corrosion inhibition of mild steel in SCW.

Oxide layer cannot exist on the steel surface below $\mathrm{pH} 4$ [16]. In absence of oxide layer, iron surface becomes bare and freely corrodes as:

$$
\mathrm{Fe}+2 \mathrm{H}^{+} \rightarrow \mathrm{Fe}^{2+}+\mathrm{H}_{2}
$$

When nitrite is added to the acidic SCW, FeOCl of very high solubility easily forms and there by accelerating corrosion.

\section{Conclusion}

- Nitrite inhibits mild steel corrosion in near neutral and alkaline media (at pH 6 and above) and accelerates in acid media (at $\mathrm{pH} 4$ and below).

- Maximum inhibition activity was attained for 500 ppm sodium nitrite at $\mathrm{pH} 8$.

- Inhibitive action of nitrite is assumed due to the oxidation of $\mathrm{Fe}_{2}^{+}$ion to form $\mathrm{Fe}_{2} \mathrm{O}_{3}$ on the surface in near neutral and alkaline region.

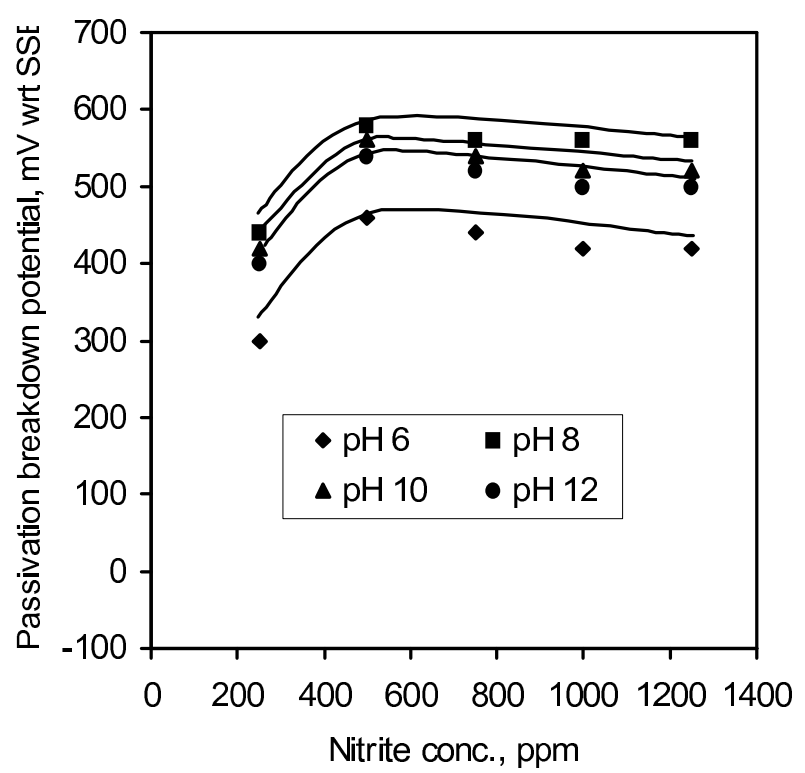

Figure 8: Effect of $\mathrm{NaNO}_{2}$ conc. on the passivation breakdown potential in SCW, soaking time, $24 \mathrm{hr}$

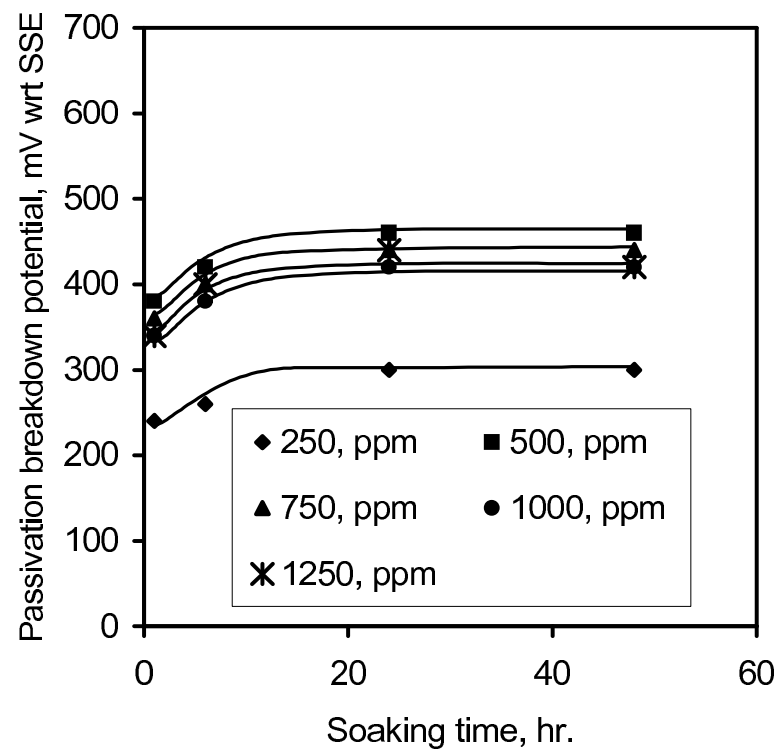

Figure 9: Effect of soaking time on the passivation breakdown potential in SCW containing $\mathrm{NaNO}_{2}$ at $\mathrm{pH} 6$

\section{References}

[1] Farooqi IH, Quraishi MA and Saini PA, Recent Trends in Cooling Water Inhibitors, in CORROSION 2000, 2000

[2] Ali MR, Mustafa CM and Habib MA, Effect of Molybdate, Nitrite and Zinc Ions on the Corrosion Inhibition of Mild Steel in Aqueous Chloride Media Containing Cupric Ions, Journal of Scientific Research, 2008. 1(1):pp. 82-91. doi:10.3329/jsr.v1i1.1053 
[3] Sakashita $\mathrm{M}$ and Sato $\mathrm{N}$, The effect of molybdate anion on the ion-selectivity of hydrous ferric oxide films in chloride solutions, Corrosion Science, 1977. 17(6):pp. 473-486. doi:10.1016/0010-938X(77) 90003-8

[4] Vukasovich MS and Robitaille DR, Corrosion inhibition by sodium molybdate, Journal of the Less Common Metals, 1977. 54(2):pp. 437448. doi:10.1016/0022-5088 (77) 90066-2

[5] Tosun A and Ergun M, Protection of Corrosion of Carbon Steel by Inhibitors in Chloride Containing Solutions, Gazi University Journal of Science, 2010. 19(3):p. 149

[6] Montes P, Bremner TW and Lister DH, Influence of calcium nitrite inhibitor and crack width on corrosion of steel in high performance concrete subjected to a simulated marine environment, Cement and Concrete Composites, 2004. 26(3):pp. 243-253. doi:10.1016/S0958-9465(03)00043-X

[7] Sideris KK and Savva AE, Durability of mixtures containing calcium nitrite based corrosion inhibitor, Cement and Concrete Composites, 2005. 27(2):pp. 277-287. doi:10.1016/j.cemconcomp.2004.02.016

[8] Ann KY, Jung HS, Kim HS, Kim SS and Moon HY, Effect of calcium nitrite-based corrosion inhibitor in preventing corrosion of embedded steel in concrete, Cement and Concrete Research, 2006. 36(3):pp. 530-535. doi:10.1016/j.cemconres.2005.09.003

[9] Ramasubramanian M, Haran BS, Popova S, Popov BN, Petrou MF and White RE, Inhibiting Action of Calcium Nitrite on Carbon Steel Rebars, Journal of Materials in Civil Engineering, 2001. 13(1):pp. 10 17. doi:10.1061/(ASCE) 0899-1561 (2001) 13:1 (10)

[10] Mustafa CM and Dulal SI, Molybdate and nitrite as corrosion inhibitors for copper-coupled steel in simulated cooling water, Corrosion, 1996. 52(1):pp. 16-22. doi:10.5006/1.3292090

[11] Afolabi AS, Synergistic Inhibition of Potassium Chromate and Sodium Nitrite on Mild Steel in Chloride and Sulphide Media, Leonardo Electronic Journal of Practices and Technologies, 2007. 11:pp. 143-154

[12] Mustafa CM and Dulal SI, Corrosion behaviour of mild steel in moderately alkaline to acidic simulated cooling water containing molybdate and nitrite, British Corrosion Journal, 1997. 32(2):pp. 133-137

[13] Vogel AI, A Text Book of Quantitative Inorganic Analysis, Longmans Publishers, London, 3rd edition, 1961

[14] Jones DA, Corrosion Processes, Applied Science Publishers, London, 3rd edition, 1982

[15] Gunasekaran G, Planiswamy N, Apparao BV and Muralidharan VS, Enhanced synergistic inhibition by calcium gluconate in low chloride media. Part I. Kinetics of corrosion, in Proceedings of the Indian Academy of Sciences - Chemical Sciences, Vol. 108, 1996. pp. 399405

[16] Uhlig HH and Revie RW, Corrosion and Corrosion Control, John Wiley and Sons, New York, 3rd edition, 1991 